\title{
KAPITALISME RUNTUH EKONOMI SYARIAH BERKAH (Napaktilas Constitutum Menuju Constituendum)
}

\author{
Mashudi, IAIN Walisongo Semarang
}

\begin{abstract}
Constitutum means discuss, evaluate and assess the role of the law that had been in force in the community, whether in accordance with the needs of society or is precisely the opposite. While constituendum interpreted efforts to create a progressive law, the law is deemed effective welfare society.

To develop and promote Islamic banks are at least teen pillars that must be considered, namely: improving service and professionalism, product innovation, buman resources, expansion of branch network, which supports the legislation, Shari'ah compliance, continuous education, synergy, the results competitive, and reorientation to the real sector.

If the government carry out its role effectively, it will be a positive contribution to the development of the community because of the need will be met, so they will be motivated through the hard work of careful and efficient. However, if it is not done, then there is destruction. The resources needed for the country's interests, acquired through the tax system fair and efficient. Similarly, if the world economy has been restless uneasy with capitalism and socialism, then ekomoni sharia in Indonesia should seriously empowered to oversee the welfare of the people.
\end{abstract}

Keyword: Ekonomi Islam, prinsip syari'ah, kapitalisme

\section{Pendahuluan}

Secara definitif Ekonomi Islam (الاقتصاد) menurut literatur Arab adalah (ekonomis) berarti kelurusan cara, dan القصد 1: (ekonomis) juga bermakna adil/keseimbangan. Ekonomis dalam satu aktivitas merupakan lawan kata dari pemborosan, yaitu sikap antara perilaku konsumtif dan penghematan yang berlebihan. Sikap ekonomis berarti tidak terlalu boros dan juga tidak terlalu kikir.

${ }^{1}$ Ahmad Warson, Kamus al-Munawir.

Volume IV/Edisi 1/Mei 2013 
Kapitalisme Runtuh Ekonomi Syariah Berkah

Adapun arti Islam, literatur Arab menyebutkan :2 Syari'at Islam berarti ketundukan untuk merealisasikan aturan serta kewajiban yang dibawa oleh Nabi Muhammad SAW. Ungkapan "seseorang adalab muslim" berarti seorang yang berserah diri terhadap perintah Allah dan ikhlas karena-Nya dalam beribadah.

Adapun secara istilah, para pakar Ekonomi Islam mendefinisikannya secara beragam, antara lain : 1. Dr. Muhammad bin Abdullah al Arabi mendefinisikan bahwa Ekonomi Islam adalah kumpulan prinsip-prinsip umum tentang ekonomi yang kita ambil dari al-Qur'an, sunnah, dan pondasi ekonomi yang kita bangun atas dasar pokok-pokok itu dengan mempertimbangkan kondisi lingkungan dan waktu. ${ }^{3}$ 2. Dr. Muhammad Syauki al Fanjari mendefinisikan bahwa Ekonomi Islam adalah segala sesuatu yang mengendalikan dan mengatur aktivitas ekonomi sesuai dengan pokok-pokok Islam dan politik ekonominya. ${ }^{4}$

Dengan demikian dapat disimpulkan bahwa ekonomi Islam adalah ilmu tentang hukum-hukum syari'at aplikatif yang diambil dari dalil-dalilnya yang terperinci tentang persoalan yang terkait dengan mencari, membelanjakan, dan cara-cara mengembangkan harta. Dengan kata lain, secara otoritatif ilmu hukum yang bersumber pada syari'ah Islam adalah mandiri, bersifat aplikatif atau 'amaliyah, dengan petunjuk dalil secara langsung spesifik.

Islam adalah agama yang paling banyak mendorong umatnya untuk menguasai perdagangan. Karena itu, Islam memberikan penghormatan yang tinggi kepada para pedagang. Dalam Sebuah hadits, Nabi Muhammad Saw, menempatkan dan mensejajarkan para pedagang bersama para Nabi, Syuhada dan Sholihin. ${ }^{5}$ Menurut Ibnu Khaldun dalam Muqaddimah, bidang ini memiliki kedudukan yang sangat vital dalam membangun peradaban Islam. Namun, masalah perdagangan (bisnis) kurang mendapat tempat dalam gerakan peradaban Islam. Padahal sektor ini sangat penting untuk diaktualisasikan kaum muslimin menuju kejayaan Islam di masa depan. Tema perdagangan ini

\footnotetext{
${ }^{2}$ Farid Wajdiy, Dairat al-Ma'arif.

${ }^{3}$ Ahmad Muhammad al-Asal dan Fathi Ahmad Karim, al-Niæ̧ham al-Iqtishadi fi al-Islam wa Mabadiubu wa Abdafubu, (Maktabah Wahbah, 1405 H), Cet. VII, hal. 15

${ }^{4}$ Centre of Islam Economic Studies. King Abd al-'Aziz University, al-Iqtishad al-Islami Bubuts Mukhtarah, Jeddah : International Conference ${ }^{1 \text { th }}$ of Islam Economy, hal. 76

5 Simak Hadits yang diriwayatkan Iman at- Tarmizi.
} 
perlu diangkat ke permukaan mengingat kondisi obyektif kaum muslimin di berbagai belahan dunia sangat tertinggal di bidang perdagangan. ${ }^{6}$

Sementara itu, pembangunan nasional Indonesia untuk mencapai terciptanya masyarakat adil dan makmur berdasarkan demokrasi ekonomi, dikembangkan sistem ekonomi yang berlandaskan pada nilai keadilan, kebersamaan, pemerataan, dan kemanfaatan yang sesuai dengan prinsip syariah. Pembangunan nasional bertujuan terciptanya masyarakat adil dan makmur berdasarkan demokrasi ekonomi, dikembangkan sistem ekonomi yang berlandaskan pada nilai keadilan, kebersamaan, pemerataan, dan kemanfaatan yang sesuai dengan prinsip syariah. Sedangkan realitas menunjukkan bahwa kebutuhan masyarakat Indonesia akan jasa-jasa perbankan syariah semakin meningkat.

Dunia telah membuktikan sekaligus merasakan bahwa sistem ekonomi kapitalisme dan sosialisme tak berdaya melawan badai krisis diberbagai sektor. Lalu, bagaimanakah kondisi tersebut akankah membawa berkah bagi ekonomi ? Makalah sederhana ini hendak mengandai-andai bagi kemajuan ekonomi syariah di Indonesia.

\section{Karakteristik dan Regulasi Ekonomi Syariah}

Sebagaimana dimaklumi bahwa aspek kehidupan bisnis dan transaksi menurut Islam berasaskan nilai-nilai dan prinsip-prinsip syariah yang bersumber dari Al Quran dan Hadits serta dilengkapi dengan Al Ijma dan Al Qiyas. Sistem perekonomian Islam, saat ini lebih dikenal dengan istilah Sistem Ekonomi Syariah, yang pada prinsipnya bertujuan : 1) Kesejahteraan Ekonomi dalam kerangka norma moral Islam. ${ }^{7}$ 2) Membentuk masyarakat dengan tatanan sosial yang solid, berdasarkan keadilan dan persaudaraan yang universal. ${ }^{8}$ 3) Mencapai distribusi pendapatan dan kekayaan yang adil dan

${ }^{6}$ Agustianto, Sekjen Ikatan Ahli Ekonomi Islam Indonesia (IAEI) dan Mahasiswa Program Doktor Ekonomi Islam UIN Jakarta, dalam salah satu beliau yang berjudul : Revitalisasi Perdagangan Syariah.

${ }^{7}$ Dasar pemikiran QS. Al-Baqarah ayat 2 \& 168, Al-Maidah ayat 87-88, Al-Jumuah ayat 10.

8 Simak QS. Al-Hujuraat ayat 13, Al-Maidah ayat 8, Asy-Syuaraa ayat 183. 
Kapitalisme Runtuh Ekonomi Syariah Berkah

merata. ${ }^{9}$ 4) Menciptakan kebebasan individu dalam konteks kesejahteraan sosial. ${ }^{10}$

Sistem ekonomi syariah mempunyai beberapa kelebihan yang tercermin dalam beberapa karakteristik, antara lain :

a. Bersumber dari Tuhan dan Agama (ربانى المصدرو التشريع)

Sumber awal ekonomi Islam ${ }^{11}$ berbeda dengan sumber sistem ekonomi lainnya karena merupakan kewajiban dari Allah. Ekonomi Islam dihasilkan dari agama Allah dan mengikat semua manusia tanpa terkecuali. Sistem ini meliputi semua aspek universal dan partikular dari kehidupan dalam satu bentuk. Dalam posisi sebagai pondasi, ekonomi syariah ${ }^{12}$ tidak berubah. Yang berubah hanyalah cabang dan bagian partikularnya, namun bukan dalam sisi pokok dan sifat universalnya.

\footnotetext{
${ }^{9}$ Simak QS. Al-Anam ayat 165, An-Nahl ayat 71, Az-Zukhruf ayat 32.

10 Simak QS. Ar-Radu ayat 36, Luqman ayat 22.

11 Prinsip Syariah adalah prinsip hukum Islam dalam kegiatan perokonomian berdasarkan fatwa yang dikeluarkan oleh lembaga yang memiliki kewenangan dalam penetapan fatwa di bidang syariah.

12 Indikator kegiatan yang berperinsip syariah meliputi: 1. menghimpun dana dalam bentuk Simpanan berupa Giro, Tabungan, atau bentuk lainnya yang dipersamakan dengan itu berdasarkan Akad wadiah atau Akad lain yang tidak bertentangan dengan Prinsip Syariah; 2. menghimpun dana dalam bentuk Investasi berupa Deposito, Tabungan, atau bentuk lainnya yang dipersamakan dengan itu berdasarkan Akad mudharabah atau Akad lain yang tidak bertentangan dengan Prinsip Syariah; 3. menyalurkan Pembiayaan bagi hasil berdasarkan Akad mudharabah, Akad musyarakah, atau Akad lain yang tidak bertentangan dengan Prinsip Syariah; 4. menyalurkan Pembiayaan berdasarkan Akad murabahah, Akad salam, Akad istishna', atau Akad lain yang tidak bertentangan dengan Prinsip Syariah; 5. menyalurkan Pembiayaan berdasarkan Akad qardh atau Akad lain yang tidak bertentangan dengan Prinsip Syariah; 6. menyalurkan Pembiayaan penyewaan barang bergerak atau tidak bergerak kepada Nasabah berdasarkan Akad ijarah dan/atau sewa beli dalam bentuk ijarah muntahiya bittamlik atau Akad lain yang tidak bertentangan dengan Prinsip Syariah; 7. melakukan pengambilalihan utang berdasarkan Akad hawalah atau Akad lain yang tidak bertentangan dengan Prinsip Syariah; 8. melakukan usaha kartu debit dan/atau kartu pembiayaan berdasarkan Prinsip Syariah; 9. membeli, menjual, atau menjamin atas risiko sendiri surat berharga pihak ketiga yang diterbitkan atas dasar transaksi nyata berdasarkan Prinsip Syariah, antara lain, seperti Akad ijarah, musyarakah, mudharabah, murabahah, kafalah, atau hawalab; 10. membeli surat berharga berdasarkan Prinsip Syariah yang diterbitkan oleh pemerintah dan/atau Bank Indonesia; 11. menerima pembayaran dari tagihan atas surat berharga dan melakukan perhitungan dengan pihak ketiga atau antarpihak ketiga berdasarkan Prinsip Syariah; 12. melakukan Penitipan untuk kepentingan pihak lain berdasarkan suatu Akad yang berdasarkan Prinsip Syariah; 13. menyediakan tempat untuk menyimpan barang dan surat berharga berdasarkan Prinsip Syariah; 14. memindahkan uang, baik untuk kepentingan sendiri maupun untuk kepentingan Nasabah berdasarkan Prinsip Syariah; 15. melakukan fungsi sebagai Wali Amanat berdasarkan Akad wakalah; 16. memberikan fasilitas letter of credit atau bank garansi berdasarkan Prinsip Syariah; dan 17. melakukan kegiatan lain yang lazim dilakukan di bidang perbankan dan di bidang sosial sepanjang tidak bertentangan dengan Prinsip Syariah dan sesuai dengan ketentuan peraturan perundang-undangan.
} 
Aturan-aturan ekonomi syariah sangat mendalam dan meyakinkan. Aturan-aturan buatan manusia tidak mungkin dapat menyamai asas dan dasar pijak legalnya. Posisi ini juga melahirkan satu sistem ekonomi yang memiliki kelebihan berupa esensinya yang mandiri dibanding sistem ekonomi lainnya. Sistem ekonomi syariah mempunyai keunggulan sebagai sebuah sistem ekonomi yang dijamin dengan hukum-hukum agama yang diwujudkan dalam aturan halal dan haram. ${ }^{13}$ Sementara sistem ekonomi lainnya, seperti kapitalis dan sosialis, tidak memiliki hukum dan landasan yang dapat mengarahkan individu dan masyarakat, sehingga sistem ini terminologi halal-haram tidak ditemukan. Oleh karena itu, sistem ini akan mengeksploitasi kegunaan, sumber daya dan kekayaan tanpa aturan dan batasan.

b. Ekonomi Pertengahan dan Berimbang (اقتصاد الوسطية و التوازن)

Ekonomi Islam memadukan kepentingan pribadi dan kemaslahatan masyarakat dalam bentuk yang berimbang. Ekonomi Islam berposisi tengah antara aliran individualis (kapitalis) yang melihat bahwa hak kepemilikan individu bersifat absolut dan tidak boleh diintervensi oleh siapapun dan aliran sosial (komunis) yang menyatakan ketiadaan hak individu dan mengubahnya ke dalam kepemilikan bersama dengan menempatkannya di bawah dominasi negara. Di antara bukti sifat pertengahan dan keberimbangan ekonomi Islam antara lain posisi tengah yang diberikan kepada negara untuk melakukan intervensi bidang ekonomi. Aliran kapitalis tidak memberikan toleransi kepada negara untuk melakukan intervensi dalam aktivitas-aktivitas ekonomi, sementara aliran sosialis melihat perlunya dominasi negara untuk melakukan intervensi dalam aktivitas ini dengan tujuan untuk meniadakan kepemilikan pribadi. Islam memperkuat posisi individu dan haknya dalam kepemilikan yang tumbuh dari perasaan tanggung jawab sosial. Islam membangun relasi individu dengan masyarakat melalui gambaran keberimbangan kongkret, yang sumbernya di atas segala kekuasaan individu dan negara, yaitu otoritas kekuasaan aturan Tuhan.

13 Yusuf Hamid al-'Alim, al-Nizham al-Siyasi wa al-Iqtishad al-Islami, (Beirut : Dar al-Qalam, 1975), Cet. I, hal. 19 
Kapitalisme Runtuh Ekonomi Syariah Berkah

Aturan ini memberikan toleransi kepada individu untuk mengambil kendali kompetisi dan kebebasan dalam menciptakan aturan-aturan yang berguna, namun tetap dalam koridor kepentingan masyarakat dan hak universalnya. (Simak QS. Al-Baqarah : 143).

c. Ekonomi Berkecukupan dan Berkeadilan (اقتصاد الكفاية والعدل)

Ekonomi Islam memiliki kelebihan dengan menjadikan manusia sebagai fokus perhatian. Manusia diposisikan sebagai pengganti Allah di bumi untuk memakmurkannya dan tidak hanya untuk mengeksplorasi kekayaan dan memanfaatkannya saja. Ekonomi ini ditujukan untuk memenuhi dan mencukupi kebutuhan manusia. Hal ini berbeda dengan ekonomi kapitalis dan sosialis dimana fokus perhatian adalah kekayaan. ${ }^{14}$ Islam telah mewajibkan negara untuk memberikan jaminan kepada semua anggota masyarakat yang berupa jaminan kebutuhan pokok bagi seluruh warga negara Islam. Kebutuhan ini telah ditentukan dalam firman Allah pada saat melakukan dialog primordial dengan Adam. (Simak QS. Thaha : 118-119)

d. Ekonomi Pertumbuhan dan Barakah

Ekonomi Islam memiliki kelebihan lain, yaitu beroperasi atas dasar pertumbuhan dan investasi harta dengan cara-cara legal, agar harta tidak berhenti dan rotasinya dalam kehidupan sebagai bagian dari mediasi jaminan kebutuhan-kebutuhan pokok bagi manusia. Islam memandang harta dapat dikembangkan hanya dengan bekerja. Hal itu hanya dapat terwujud dalam usaha keras untuk menumbuhkan dan memperluas unsur-unsur produksi demi terciptanya hasil yang lebih baik. Usaha itu dilakukan melalui perputaran modal di tengah masyarakat Islam dalam bentuk modal produksi sebagai kontribusi dalam aturan-aturan yang dikembangkan.

Islam melarang secara keras praktek monopoli, penumpukan dan penghentian pengalokasian dan perputaran. Islam juga melarang dengan keras pengalokasian harta terhadap orang yang mengutamakan harta dengan kebodohan dalam mengolahnya. Allah memberikan

${ }^{14}$ Muhammad 'Abd al-Mun'am al-Jamal, Mausu'at al-Iqtishad al-Islami, (Kairo : Dar Kitab al-Mishri, 1980), hal. 15 
julukan "orang yang mementingkan kemewahan" sebagai golongan berdosa. (Simak QS. Hud : 116)

Dalam studi ekonomi Islam, diketahui bahwa ada pilar-pilar yang menjadi landasannya, yaitu : Pertama, Kepemilikan Ganda (kepemilikan khusus dan kepemilikan umum). Penggunaan keduanya dikategorikan sebagai pemilikan ganda. Ekonomi Islam dibangun di atas dua macam pemilikan itu secara bersamaan. Pada saat bersamaan, Islam menetapkan kepemilikan personal dan kepemilikan sosial serta ada bidang luas bagi keberlakuan dua jenis kepemilikan ini.

Sementara karakteristik lain ekonomi Islam adalah penciptaan keseimbangan antara kepentingan personel dan kepentingan sosial. Dua kepentingan ini dikatakan seimbang selama tidak ada pertentangan antar keduanya, atau dimungkinkan adanya penggabungan antar keduanya. Jika terdapat kontradiksi antar kepentingan personal dengan kepentingan sosial dan terdapat kesulitan untuk menciptakan adanya keseimbangan atau penggabungan antar keduanya, maka Islam lebih memprioritaskan kepentingan sosial dibanding kepentingan personal.

Dasar legal formal sikap ini adalah sebuah hadis yang diriwayatkan dari Ibnu Abbas ra bahwa Nabi Muhammad SAW bersabda ;

$$
\text { ولايبيع حاضر لباد (رواه الجماعة الاالترمذى) }
$$

"Pendudukan yang menetap tidak boleh menjual permadani kepada pengembara".

Sebagai gambaran, penduduk suatu daerah mempunyai kecenderungan untuk menjual barang kepada seseorang yang menawar lebih tinggi, walaupun kepada pendatang. Ia tidak mempertimbangkan kebutuhan penduduk lokal. Dalam kondisi sangat membutuhkan, praktek semacam ini dilarang karena mengabaikan kebutuhan warga sekitar dan mengingat kepentingan penduduk asli lebih utama.

Dasar legal lainnya adalah sabda Nabi Muhammad SAW sebagai tanggapan atas perkataan Jabir :

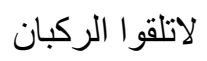

"Jangan mencegat kafilah pedagang di tengah jalan". 
Kapitalisme Runtuh Ekonomi Syariah Berkah

Orang yang mencegat di tengah jalan mempunyai kecenderungan untuk membeli dengan harga lebih murah dan menjual kembali secara berlipat, sedangkan ia berposisi sebagai pribadi. Kondisi semacam ini dilarang agar sebagian besar kelompok masyarakat dapat mengambil manfaat dengan jalan membeli langsung dari pedagang dengan pertimbangan harga yang lebih murah. ${ }^{15}$

Sebagian ahli fiqih memperbolehkan mengambil makanan secara paksa dari kelompok yang melakukan monopoli dan kemudian menjualnya kepada masyarakat. ${ }^{16} \mathrm{Di}$ sinilah terlihat bagaimana Islam lebih mengutamakan kepentingan sosial dibanding kepentingan personal jika kepemilikan itu menyangkut kepentingan masyarakat secara luas.

Kedua, Kebebasan Ekonomi yang Terikat. Limitasi kebebasan dalam ekonomi Islam dimaksudkan sebagai perwujudan aturan syariat dalam hal menggali dan menggunakan kekayaan. Sistem ini berbeda dengan sistem kapitalis yang memberikan kebebasan mutlak dan menciptakan individu dengan kebebasan tanpa batas dalam pencarian dan penggunaan kekayaan. Sistem ekonomi Islam juga berbeda dengan sistem ekonomi sosialis yang mensentralkan kepemilikan, sehingga manusia dilarang untuk berkreasi dalam kepemilikan. Aturan-aturan syari'at sesungguhnya ingin mengarah kebebasan pada tiga hal :

a. Hendaknya kegiatan ekonomi itu legal secara hukum dan sesuai dengan asas halal, haram, dan nilai-nilai moral. Batasan ini menghubungkan ekonomi Islam dengan ketaatan dan ibadah kepada Allah sehingga semua perbuatan dan pekerjaan manusia selalu bernilai ibadah. Wilayah halal itu lebih luas dan lebih lapang karena pokok segala sesuatu dalam bidang muamalah adalah boleh, sedang wilayah haram itu sempit. Oleh karena itu, Islam tidak menentukan jenis pekerjaan yang diperbolehkan secara spesifik. Islam hanya menerangkan nash yang menerangkan jenis pekerjaan yang diharamkan. Pengharaman ini ditujukan untuk

${ }^{15}$ Ibnu Taymiyah, al-Hasbah fi al-Islam, (Riyadh : Percetakan Negara, t.th), hal. 79-60

16 Ibid 
mencegah adanya kerusakan, kezhaliman, dan memelihara dari kemudlaratan. ${ }^{17}$

b. Jaminan hak negara untuk melakukan intervensi demi menjaga dan memelihara kepentingan umum dengan memberikan hak untuk membatasi kebebasan-kebebasan personal dalam praktek kegiatan ekonomi yang tidak sesuai dengan tuntutan dan ajaran Islam. Pemerintah tertinggi menurut Islam mempunyai hak untuk ditaati selama masih berada dalam jalur syari'at. (simak QS. Al-Nisa 59). Kaidah ushul yang mengatur hal ini adalah sabda Nabi Muhammad SAW : "Jangan melakukan perbuatan yang membahayakan diri dan yang membahayakan orang lain". ${ }^{18}$

c. Sebagai pendidikan bagi kaum muslim untuk mengutamakan kepentingan orang lain atas kepentingan pribadi. Seorang muslim harus menghentikan kegiatan yang mendatangkan keuntungan materi jika hanya akan juga mendatangkan kerugian bagi orang lain.

Di bawah naungan Islam, manusia akan merasakan tumbuhnya solidaritas terhadap orang lain dan mengarahkan kebebasannya pada arah yang terkontrol secara baik tanpa ada perasaan bahwa ada hak yang terampas. Islam menjaga hak setiap orang. Dengan demikian, seorang muslim tidak akan merasakan kebebasan hakiki manakala berada dalam naungan selain nilai-nilai Islam, oleh karena dikenal dalam Islam dikenal limitasi kebebasan ekonomi : a) Pemilik hakiki segala sesuatu tidak lain adalah Allah SWT. Ia memiliki hak prerogatif untuk membatasi kegiatan penggalian dana yang dilakukan oleh manusia sesuai dengan tuntunan dan aturan yang ditetapkan-Nya. Hal ini dikarenakan Dia Maha Tahu hal-hal yang maslahat bagi manusia dan kondisikondisi terbaik bagi mereka. b) Tidak diperkenankan adanya satu keadaan yang membahayakan hak orang lain atau kepentingan publik. c) Adanya jaminan kepentingan kelompok lemah dari rivalitas dan persaingan dengan kelompok kuat sebagaimana tercermin dalam sasaran zakat, kewajiban memberikan nafkah bagi para kerabat, dan perhatian yang diberikan kepada golongan fakir

${ }^{17}$ Setiap larangan terhadap satu aktivitas tidak lain diarahkan agar perilaku itu sesuai dengan tujuan-tujuan Islam, ketinggian moral, dan kesucian jiwa, seperti riba', monopoli, manipulasi, penipuan dan setiap transaksi fiktif.

${ }^{18}$ Hadits Mursal diriwayatkan oleh malik dan Ahmad dari sahabat Ibnu 'Abbas. 
Kapitalisme Runtub Ekonomi Syariab Berkah

dan kelompok-kelompok masyarakat yang kekurangan. d) Adanya kewajiban suatu kelompok untuk melaksanakan kewajiban publik yang telah dibebankan kepada mereka seperti pengadaan sarana pendidikan, rumah sakit, jalan umum dan fasilitas umum lainnya.

Ketiga, Jaminan Sosial. Salah satu karakter kodrati adalah kenyataan yang menunjukkan bahwa masing-masing manusia memiliki perbedaan fisik, karakter jiwa, dan kemampuan intelektual. Mereka berbeda dalam kekuatan fisik dan susunan tulang tubuh yang dimiliki. Mereka juga berbeda dalam keteguhan hati, kekuatan untuk bersikap sabar dan keberanian jiwa. Batas kecerdasan, kepekaan reaksi terhadap kondisi sosial, dan karakter-karakter personal manusia lainnya juga dimiliki dalam kapasitas berbeda.

Selama perbedaan ini masih tampak dalam potensi, bakat, karakter jasmani dan jiwa, maka hasil pekerjaan yang ditunjukkan oleh manusia tidak hadir dalam bentuk tunggal yang pada akhirnya mempengaruhi manusia dalam menghasilkan kekayaan. Untuk membantu orang yang tidak memungkinkan untuk menghasilkan kekayaan secara mandiri, maka Islam menggariskan adanya jaminan sosial dan keberimbangan antar anggota masyarakat sebagai bentuk penolakan adanya kesenjangan mencolok dalam level penghasilan. ${ }^{19}$

\section{Kapitalisme Runtuh Ekonomi Syariah Berkah}

Ketika sistem ekonomi kapitalisme mengalami kerapuhan dan keruntuhan, maka peluang (chance) ekonomi syariah makin terbuka luas untuk berkembang dan menjadi solusi sistem perekonomian dunia. Gejala tersebut semakin menunjukkan realitanya ketika 75 negara di dunia telah mempraktekkan sistem ekonomi dan keuangan Islam, baik di Asia, Eropa, Amerika maupun Australia. Demikian pula dalam bidang akademis, beberapa universitas terkemuka di dunia sedang giat mengembangkan kajian akademis tentang ekonomi syariah. Harvard University merupakan universitas yang aktif mengembangkan forum dan kajian-kajian ekonomi syariah tersebut. Di Inggris setidaknya enam universitas mengembangakan kajian-kajian ekonomi syari'ah.

${ }^{19}$ Centre of Islami Economic Studies, al-Iqtishad al-Islami, hal. 99 
Demikian pula di Australia oleh Mettwally dan beberapa negara Eropa seperti yang dilakukan Volker Ninhaus.

Di Indoinesia, justru sebaliknya, masih banyak pakar ekonomi dari kaum muslimin yang masih memiliki paradigma sekuler sehingga belum tertarik kepada ekonomi Islam karena belum mempelajari dan belum mengerti tentang ekonomi Islam tersebut. Seandainya mereka secara jujur dan pikiran yang jernih mempelajarinya, niscaya mereka akan tertarik dan berdecak kagum melihat keunggulan ekonomi ilahiyah ini.

Ketika sistem ekonomi kapitalisme mengalami keruntuhan, eksistensi ekonomi syariah yang baru tumbuh dalam tiga dekade terakhir, makin memiliki prospek yang positif dan cerah. Ekonomi Syari'ah ${ }^{20}$ merupakan sistem ekonomi post-capitalist yang berperan sebagi solusi ekonomi dunia. Semoga para ilmuwan ekonomi Islam saat ini dapat mengisi peluang besar yang sangat strategis itu dengan ijtihad ekonomi yang lebih kreatif dan inovatif berdasarkan nilai-nilai syari'ah untuk mewujudkan tata ekonomi dunia yang berkeadilan.

Kegagalan kapitalisme membangun kesejahteran umat manusia di muka bumi, maka isu kematian ilmu ekonomi semakin meluas di kalangan para cendikiawan dunia. Banyak pakar yang secara khusus menulis buku tentang The Death of Economics tersebut, antara lain Paul Omerod, Umar Ibrahim Vadillo, Critovan Buarque, dsb. ${ }^{21}$

Paul Omerod dalam buku The Death of Economics (1994), sebagaimana dalam Agustianto, enuliskan bahwa ahli ekonomi terjebak pada ideologi kapitalisme yang mekanistik yang ternyata tidak memiliki kekuatan dalam membantu dan mengatasi resesi ekonomi yang melanda dunia. Mekanisme pasar yang merupakan bentuk dari sistem yang diterapkan kapitalis cenderung pada pemusatan kekayaan pada kelompok orang tertentu. Senada dengan buku Omerod, muncul pula Umar Vadillo dari Scotlandia yang menulis buku, 'The

20 Akad adalah kesepakatan tertulis antara Bank Syariah atau UUS dan pihak lain yang memuat adanya hak dan kewajiban bagi masing-masing pihak sesuai dengan Prinsip Syariah.

21 Agustianto, Sekjen Ikatan Ahli Ekonomi Islam Indonesia (IAEI) dan Dosen Ekonomi Syariah Pascasarjana PSTTI UI dalam Kematian Ilmu Ekonomi Kapitalisme dan Peluang Ekonomi Syariah. 
Kapitalisme Runtub Ekonomi Syariab Berkah

Ends of Economics" yang mengkritik secara tajam ketidakadilan sistem moneter kapitalisme. Kapitalisme justru telah melakukan "perampokan" terhadap kekayaan negara-negara berkembang melalui sistem moneter fiat money yang sesungguhnya adalah riba.

Dari berbagai analisa para ekonom dapat disimpulkan, bahwa teori ekonomi telah mati karena beberapa alasan. Pertama, teori ekonomi Barat (kapitalisme) telah menimbulkan ketidakadilan ekonomi yang sangat dalam, khususnya karena sistem moneter yang hanya menguntungkan Barat melalui hegemoni mata uang kertas dan sistem ribawi. Kedua, Teori ekonomi kapitalisme tidak mampu mengentaskan masalah kemiskinan dan ketimpangan pendapatan. Ketiga, paradigmanya tidak mengacu kepada kepentingan masyarakat secara menyeluruh, sehingga ada dikotomi antara individu, masyarakat dan negara. Keempat, Teori ekonominya tidak mampu menyelaraskan hubungana antara negara-negara di dunia, terutama antara negara-negara maju dan negara berkembang. Kelima, terlalaikannya pelestarian sumber daya alam.

Alasan-alasan inilah yang oleh Mahbub al-Haq (1970) dianggap sebagai dosa-dosa para perencana pembangunan kapitalis. Kesimpulan ini begitu jelas apabila pembahasan teori ekonomi dihubungkan dengan pembangunan di negara-negara berkembang. Sementara itu perkembangan terakhir menunjukkan bahwa kesenjangan antara negara-negara berpendapatan tinggi dan negara-negara berpendapatan rendah, tetap menjadi indikasi bahwa globalisasi belum menunjukkan kinerja yang menguntungkan bagi negara miskin. (The World Bank, 2002).

Karena kegagalan kapitalisme itulah, maka sejak awal, Joseph Schumpeter meragukan kapitalisme. Dalam konteks ini ia mempertanyakan, "Can Capitalism Survive"?. No, I do not think it can. (Dapatkah kapitalisme bertahan?. Tidak, saya tidak berfikir bahwa kapitalisme dapat bertahan). Selanjutnya ia mengatakan, "Capitalism would fade away with a resign shrug of the shoulders", Kapitalisme akan pudar/mati dengan terhentinya tanggung jawabnya untuk kesejahteraan. ${ }^{22}$

22 Simak Heilbroner dalam salah satu statemen di tahun 1992. 
Sejalan dengan pandangan para ekonom di atas, pakar ekonomi Fritjop Chapra mengungkapkan bahwa ekonomi konvensional (kapitalisme) yang berlandaskan sistem ribawi, memiliki kelemahan dan kekeliruan yang besar dalam sejumlah premisnya, terutama rasionalitas ekonomi yang telah mengabaikan moral. Kelemahan itulah menyebabkan ekonomi (konvensional) tidak berhasil menciptakan keadilan ekonomi dan kesejahteraan bagi umat manusia. ${ }^{23}$ Yang terjadi justru sebaliknya, ketimpangan yang semakin tajam antara negara-negara dan masyarakat yang miskin dengan negara-negara dan masyarakat yang kaya, demikian pula antara sesama anggota masyarakat di dalam suatu negeri. Lebih lanjut mereka menegaskan bahwa untuk memperbaiki keadaan ini, tidak ada jalan lain kecuali mengubah paradigma dan visi, yaitu melakukan satu titik balik peradaban, dalam arti membangun dan mengembangkan sistem ekonomi yang memiliki nilai dan norma yang bisa dipertanggungjawabkan ${ }^{24}$.

\section{Ekonomi Syariah : dari Constitutum menuju Constituendum}

Constitutum berarti memperbincangkan, mengevaluasi peran dan menilai perangkat hukum yang selama ini berlaku di masyarakat, apakah sesuai dengan kebutuhan masyarakat ataukah justeru sebaliknya. Sedangkan constituendum dimaknai upaya mewujudkan hukum yang progresif, hukum yang dipandang efektif menyejahterakan masyarakatnya. ${ }^{25}$

Berbagai studi tentang hubungan hukum dan pembangunan ekonomi menunjukkan bahwa pembangunan ekonomi tidak akan berhasil tanpa pembaharuan hukum. Memperkuat institusi-institusi hukum adalah "precondition

\footnotetext{
${ }^{23}$ Selanjutnya simak Fritjop Chapra dalam, The Turning Point, Science, Society and The Rising Culture (1999) dan Ervin Laszio dalam buku 3rd Millenium, The Challenge and The Vision (1999),

${ }_{24}$ Selanjutnya simak titik balik peradaban versi Fritjop Chapra sangat sesuai dengan pemikiran Kuryid Ahmad ketika memberi pengantar buku Umar Chapra, "The Future of Economics : An Islamic Perspective (2000), yang mengharuskan perubahan paradigma ekonomi. Hal yang sama juga ditulis oleh Amitai Etzioni dalam buku, 'The Moral Dimension : Toward a New Economics"(1988), yakni kebutuhan akan paradigm shift (pergeseran paradigma) dalam ekonomi. Sejalan dengan pandangan para ilmuwan di atas, Critovan Buarque, ekonom dari universitas Brazil dalam buknya, "The End of Economics" Ethics and the Disorder of Progress (1993), melontarkan sebuah gugatan terhadap paradigma ekonomi kapitalis yang mengabaikan nilai-nilai etika dan sosial.

${ }^{25}$ Disarikan dari kuliah Prof. Satjipto Rahardjo dan Prof. Soetandjo Wignyjosoebroto pada Program Doktor Ilmu Hukum (PDIH) Unidip Semarang.
} 
Kapitalisme Runtub Ekonomi Syariab Berkah

for economic change", "crucial to the viability of new political system", and "an agent of social change". Agar hukum dapat berperan dalam pembangunan ekonomi nasional maka hukum di Indonesia harus memenuhi lima kualitas, yaitu: kepastian (predictability), stabilitas (stability), keadilan (fairness), pendidikan (education), dan kemampuan SDM di bidang hukum (special abilities of the lanyer).

Kebutuhan akan kepastian fungsi hukum besar sekali, khususnya bagi negara-negara dimana sebagian besar rakyatnya baru pertama kali memasuki hubungan-hubungan ekonomi melampaui lingkungan sosial yang tradisional.Hukum harus dapat menjamin investasi asing, bagaimana penyelesaian yang adil dan jaminan hukum terhadap hasil yang mereka peroleh.

Stabilitas adalah potensi hukum menyeimbangkan dan mengakomodasi nilai-nilai atau kepentingan-kepentingan yang saling bersaing dalam masyarakat sehingga akan berdampak timbulnya stabilitas. Oleh karena itu pemenuhan akan kebutuhan perundang-undangan yang mentranformasikan nilai-nilai syariah sebagai konsekuensi dari tumbuhnya kesadaran beragama dari masyarakat untuk melaksanakan ajaran agamanya menjadi faktor penting untuk diperhatikan sebagai bagian dari upaya pertumbuhan ekonomi.

Keadilan (fairness) adalah bagaimana hukum menjamin adanya perlindungan, perlakuan yang sama dan adanya standar tingkah laku pemerintah untuk memelihara mekanisme pasar dan pencegahan ekses-ekses birokratis yang berlebihan. Ketiadaan standar keadilan merupakan masalah terbesar yang dihadapi negara-negara berkembang. Dalam kurun waktu yang lama, hal tersebut bisa menjadi penyebab utama hilangnya legitimasi pemerintah.

Pendidikan berkaitan erat dengan pemberian tujuan, yaitu kemampuan hukum sebagai suatu kekuatan pembentuk kebiasaan-kebiasaan (babits) yang dapat memperkuat kebiasaan lama atau meciptakan respon baru dan kondisikondisi tertentu. Di Indonesia, hukum (undang-undang) belum dapat sepenuhnya berfungsi pendidikan, atau melakukan fungsi social change. Yang diharapkan di Indonesia adalah bagaimana hukum dapat mendisiplinkan masyarakat dan menciptakan lingkungan usaha yang sehat. Sedangkan SDI (sumber daya Insani) bermakna bahwa sarjana hukum, memainkan peranan 
yang penting untuk membawa perubahan kepada sistem norma-norma dan nilai-nilai baru dalam tiap tahap pembangunan. Maka dalam rangka mendorong pemulihan perekonomian dituntut adanya kemampuan khusus para sarjana hukum untuk $\mathrm{m} \backslash$ enjalankan hukum tersebut.

Oleh karena itu dibutuhakan political will karena kemunculan ekonomi syariah pada ranah politik hukum. ${ }^{26}$ Dari penjelasan tersebut, politik hukum adalah arahan atau garis resmi yang dijadikan dasar pijak dan cara untuk membuat dan melaksanakan hukum dalam rangka mencapai tujuan bangsa dan negara. Politik hukum merupakan upaya menjadikan hukum sebagai proses pencapaian tujuan negara. Politik hukum dapat dikatakan juga sebagai jawaban atas pertanyaan tentang mau diapakan hukum itu dalam perspektif formal kenegaraan guna mencapai tujuan negara. ${ }^{27}$ Kendatipun secara yuridis, penerapan hukum ekonomi syariah di Indonesia memiliki dasar yang sangat kuat, sebagaimana dalam ketentuan Pasal 29 UUD 1945.

Itulah sebabnya menurut Jimly Asshiddiqie, Prinsip Ketuhanan Yang Maha Esa diwujudkan melalui prinsip birarki norma dan elaborasi norma. Dalam konteks sistem hirarki norma, perlu dibedakan antara pengertian syariat dengan figh dan dengan qanun. Menurut logika sistem hirarki itu, maka dalam prinsip pertama, hukum suatu negara berisi norma-norma yang tidak boleh bertentangan dengan norma yang terkandung di dalam syariat agama-agama yang dianut oleh warga masyarakat. Sedangkan dalam prinsip yang kedua, norma-norma yang tercermin dalam rumusan-rumusan hukum negara, haruslah merupakan penjabaran atau elaborasi normatif ajaran-ajaran syari'at agama yang diyakini oleh warga negara. ${ }^{28}$

Perkembangan politik hukum ekonomi syariah diawali di bidang perbankan, yaitu dengan keluarnya UU No. 7 Tahun 1992 tentang

26 Menurut Moh.Mahfud MD, politik hukum adalah legal policy yang akan atau telah dilaksanakan secara nasional oleh Pemerintah Indonesia yang meliputi: pertama, pembangunan hukum yang berintikan pembuatan dan pembaruan terhadap materi-materi hukum agar dapat sesuai dengan kebutuhan; kedua, pelaksanaan ketentuan hukum yang telah ada termasuk penegasan fungsi-fungsi lembaga dan pembinaan para penegak hukum.

27 Simak Agustianto, Politik. Hukum dalam Ekonomi Syariah, makalah lepas.

28 Agus tianto, ibid. 
Kapitalisme Runtub Ekonomi Syariah Berkah

Perbankan ${ }^{29}$ yang kemudian diubah dengan UU No. 10 Tahun $1998^{30}$ tentang Perubahan Undang-Undang Nomor 7 Tahun 1992. Eksistensi bank syariah semakin diperkuat kuat dengan adanya UU No. 23 Tahun 1999 tentang Bank Indonesia, yang menyatakan bahwa Bank Indonesia dapat menerapkan kebijakan moneter berdasarkan prinsip-prinsip syariah. ${ }^{31}$ Kedua UU tersebut menjadi landasan hukum bagi perbankan nasional untuk menerapkan sistem perbankan ganda atau dual banking system.. Bahkan melalui PBI No. 8/3/PBI/2006 telah dikeluarkan kabijakan office chanelling

Perbankan syariah memiliki kekhususan dibandingkan dengan perbankan konvensional. Pengaturan mengenai perbankan syariah di dalam Undang-Undang Nomor 7 Tahun 1992 tentang Perbankan sebagaimana telah diubah dengan Undang-Undang Nomor 10 Tahun 1998 belum spesifik sehingga perlu diatur secara khusus dalam suatu undang-undang tersendiri. Sementara itu, berdasarkan rekapitulasi hasil pengamatan secara makro Agustianto $^{32}$ menuturkan bahwa perkembangan industri perbankan dan keuangan syariah dalam satu dasawarsa belakangan ini mengalami kemajuan yang sangat pesat, seperti perbankan syariah, asuransi syariah, pasar modal syariah, reksadana syariah, obligasi syariah, pegadaian syariah, Baitul Mal wat Tamwil (BMT). Demikian pula di sektor riil, seperti Hotel Syariah, Multi Level Marketing Syariah, dsb. Perkembangan perbankan menurut data Bank Indonesia mengalami kemajuan yang spektakuler. ${ }^{33}$

Untuk mengembangkan dan memajukan bank syariah setidaknya ada 10 pilar yang harus diperhatikan, yakni : peningkatan pelayanan dan profesionalisme, inovasi produk, sumber daya insani, perluasan jaringan

${ }^{29}$ Berdasarkan UU No. 7 Tahun 1992 itu bank syariah dipahami sebagai bank bagi hasil. Selebihnya bank syariah harus tunduk kepada peraturan perbankan umum yang berbasis konvensional.

${ }^{30}$ Dengan diberlakukannya UU No. 10 Tahun 1998 tentang Perubahan Atas UU No. 7 Tahun 1992 tentang Perbankan, landasan hukum bank syariah menjadi cukup jelas dan kuat, baik dari segi kelembagaannya maupun landasan operasionalnya. Dalam UU ini ‘prinsip syariah' secara definitif terakomodasi.

${ }^{31}$ Simak UU No. 23 Tahun 1999 tentang Bank Indonesia Pasal 1 angka 7 dan pasal 11).

32 Sekjen Ikatan Ahli Ekonomi Islam Indonesia (IAEI) dan Dosen Pascasarjana PSTTI UI Kekhususan Ekonomi dan Keuangan Islam.

33 Agustianto, Sekjen Ikatan Ahli Ekonomi Islam Indonesia (IAEI) dan Mahasiswa Program Doktor Ekonomi Islam UIN Jakarta, dalam salah satu beliau yang berjudul : 10 Pilar Pengembangan Bank Syariah. 
kantor, peraturan yang mendukung, syari'ah compliance, edukasi yang kontinyu, sinergi, bagi hasil yang kompetitif, dan reorientasi ke sektor riil.

Model Dinamika adalah sebuah rumusan yang terdiri dari delapan prinsip kebijaksanaan politik yang terkait dengan prinsip yang lain secara interdisipliner dalam membentuk kekuatan bersama dalam satu lingkaran sehingga awal dan akhir lingkaran tersebut tidak dapat dibedakan, terdiri atas : 1. Kekuatan pemerintah tidak dapat diwujudkan kecuali dengan implementasi Syariah; 2. Syariah tidak dapat dilaksanakan kecuali dengan pemerintahan; 3. Pemerintah tidak dapat memperoleh kekuasaan kecuali dari rakyat; 4. Masyarakat tidak dapat ditopang kecuali oleh kekayaan; 5. Kekayaan tidak dapat diperoleh kecuali dari pembangunan; 6. Pembangunan tidak dapat dicapai kecuali melalui keadilan; 7. Keadilan merupakan standar yang akan dievaluasi Allah pada umat-Nya; 8. Pemerintah dibebankan dengan adanya tanggung jawab untuk mewujudkan keadilan.

\section{Ikhtitam}

Ajaran welfare state Islami, mengupayakan agar setiap orang mengikuti ajaran Syariah dalam urusan duniawi dan ukhrawi. Negara harus tetap mengawasi semua tingkah laku yang dapat membahayakan pembangunan sosial ekonomi seperti ketidakjujuran, penipuan, dan ketidakadilan sebagai prasyarat kualitas yang dibutuhkan untuk keharmonisan sosial dan pembangunan berdasarkan keadilan. Selain itu, negara harus menjamin pemenuhan hukum dan menghormati hak milik individu serta menanamkan kesadaran kepada seluruh lapisan masyarakat.

Apabila pemerintah melaksanakan peranannya secara efektif, maka akan menjadi sebuah kontribusi positif dalam pembangunan karena kebutuhan masyarakat akan terpenuhi, sehingga mereka akan termotivasi melalui kerja keras yang cermat dan efisien. Namun, jika hal itu tidak terlaksana, maka yang terjadi adalah kehancuran. Sumber daya yang dibutuhkan negara untuk kepentingan itu, diperoleh melalui sistem pajak yang adil dan efisien. Begitu pula, kalau dunia telah resah gelisah dengan ekonomi kapitalisme dan sosialisme, maka ekomoni syariah di Indonesia hendaknya diberdayakan secara sungguh-sungguh untuk mengawal kesejahteraan umat. 
Kapitalisme Runtub Ekonomi Syariah Berkah

\section{DAFTAR PUSTAKA}

Agustianto dalam Makalah berjudul : a. Politik Hukum dalam Ekonomi Syariab; $b$. Membangun Sinergi Untuk Kebangkitan Ekonomi Indonesia; c. Kematian Ilmu Ekonomi Kapitalisme dan peluang Ekonomi Syariah; dan d. Ekonomi Syariah dan Peradilan Agama.

A.K, Syakmin, Mengkritisi Pandangan Mochtar Kusuma Atmaja Yang Mengintrodusir Hukum Sebagai Sarana Pembaharuan Masyarakat di Indonesia, Draft Makalah, Tidak diterbitkan, Palembang, tanpa tahun.

Azlan Khalil Shamsudin dan Siti Khursiah Mohd Mansor, Pengantar Ekonomi Islam, iBook, 2006.

Darmodiharjo, Darji dan Sidharta, Pokok-Pokok Filsafat Hukum, Gramedia Pustaka Utama, Jakarta, 1995.

Inpres Nomor 1 Tahun 1991 Tentang KHI.

Khairi, Nuri Dkk, Membedah Peradilan Agama, PPHIM Jateng, 2001.

Kusumaatmadja, Mochtar, dalam Soetandyo Wignjosoebroto, Dari Hukum Kolonial Ke Hukum Nasional: Dinamika Sosial Politik dan Perkembangan Hukum di Indonesia, Jakarta, Rajawali Press, 1994.

- Pembinaan Hukum Dalam Rangka Pembangunan Hukum Nasional, PT. Binacipta, Bandung, 1986.

Mahkamah Agung, Pedoman Teknis Administrasi dan Teksin Peradilan Agama, 2009 (Buku II).

Mustafa Dakian, Sistem Kewangan Islam, Utusan Publications, 2005.

Manan, Abdul, Prof. Dr. Penerapan Hukum Acara Perdata di Lingkungan Peradilan Agama, Jakarta, 2000.

Mujahidin, Ahmad, DR. Pembaharuan Hukum Acara Perdata Peradilan Agama dan Mabkamah Syari'ah di Indonesia, Jakarta, 2008.

Muntaqo, Firman, Efektifitas Hukum Sebagai Alat Rekayasa Sosial, Jurnal Hukum Progressif, PDIH Undip Semarang, 2005 
Paton, G.W. A Text-book of Jurisprudence, 2nd. Ed, Oxford University Press, London, 1951.

Purbacaraka, Purnadi dan Chidir Ali, Disiplin Hukum, Citra Aditya Bhakti, Bandung, 1990.

Peraturan Pemerintah. Nomor 9 Tahun 1975 Tentang Pelaksanaan UndangUndang Nomor 1 Tabun 1974.

Peraturan Mahkamah Agung 2 Tahun 2008 Tentang Kompilasi Hukum Ekonomi Syariah.

Peraturan Mentri Agama Nomor 11 Tahun 2007 Tentang Pencatatan Nikah.

Rasjidi Lily, Filsafat Hukum: Apakah Hukum Itu?’ CV. Remadja Karya, Bandung, 1988.

Rahardjo, Satjipto, Imu Hukum, Alumni, Bandung, 2002.

---------, Hukum Adat Dalam Negara Kesatuan Republik Indonesia Perspektif Sosiologi Hukum), Makalah disampaikan pada Lokakarya Hukum Adat diselenggarakan oleh Mahkakamah Konstitusi 4-6 Juni 2005.

Rasyidi, Lili, Dasar-Dasar Filsafat Hukum, Citra Aditya, Bandung, 1990.

Seidman, Robert B. dalam Ronny Hanitijo Soemitro, The Law of Nontransferability of Law Menurut Robert B. Seidman, Badan Penerbit Universitas Diponegoro, Semarang, 1998.

Surat Edaran Mahkamah Agung Nomor 08 Tahun 2008 Tentang Eksekusi Putusan Badan Arbritrase Syariah.

Sarimah Hanim Aman Shah, Ekonomi dari Perpektif Islam, Penerbit Fajar Bakti, 2006.

Surtahman Kastin Kasan dan Sanep Ahmad, Ekonomi Islam: Dasar dan Amalan, Dewan Bahasa dan Pustaka, Edisi Kedua, 2005.

Surtahman K.H. dan Sanep Ahmad, Ekonomi Islam: Dasar dan Amalan, DBP, 2005, xx-xxi.

Undang-Undang Nomor 1 Tahun 1974 Tentang Perkawinan.

Undang-Undang Nomor 7 Tahun 1989 Tentang Peradilan Agama.

Volume IV/Edisi 1/Mei 2013 
Kapitalisme Runtub Ekonomi Syariah Berkah

Undang-Undang Nomor 3 Tahun 2006 Tentang Perobahan atas Undang-Undang Nomor 7 Tabun 1989.

Undang-Undang Nomor 50 Tahun 2009 Tentang Perobahan kedua UndangUndang Nomor 7 Tabun 1989.

Undang-Undang Nomor 48 Tahun 2009 Tentang Kekuasaan Kehakiman.

Undang-Undang N 212008 Tentang Perbankan Syari'ah.

Virginia Hooker and Amin Saikal (editors), Islamic Perspectives on the New Millenium, ISEAS, 2004. 